Authors: Michał Mendak, Michał Wieczorowski, Karol Grochalski, Bartosz Gapiński

Title of article: „Wiarygodność pomiaru mikroskopowego geometrii frezu kulistego oraz jej wpływ na nierówności powierzchni po frezowaniu kopiowym" ("Credibility of the microscopic measurement of the tool geometry and its influence on surface asperity after ball end milling")

Mechanik, Vol. 91, No. 8-9 (2018): pages 710-712

DOI: https://doi.org/10.17814/mechanik.2018.8-9.112

\title{
Credibility of the microscopic measurement of the tool geometry and its influence on surface asperity after ball end milling
}

\author{
Wiarygodność pomiaru mikroskopowego geometrii frezu kulistego \\ oraz jej wpływ na nierówności powierzchni po frezowaniu kopiowym
}

\author{
MICHAK MENDAK \\ MICHAŁ WIECZOROWSKI \\ KAROL GROCHALSKI \\ BARTOSZ GAPIŃSKI *
}

\begin{abstract}
New ball end mills in various lighting conditions were examined and detailed 3D models were obtained. Differences in the geometry of the tool tip resulted in a surface with drastically different parameters. The effect of the edge break was observed. The obtained 3D models were used to create a map of the material loss on the cutting edge of cutting tool.

KEYWORDS: turning, focus variation microscope, toolwear analysis, surface topography
\end{abstract}

Observation of the tool wear process and the impact of its geometry on the obtained surface unevenness have been the subject of many studies and publications [1-4] Often, parameterized consumption descriptions are given, providing only the maximum values of losses, but this approach seems insufficient to accurately trace the tool wear and location of its outbreaks.

The use of a focal differentiation microscope for this purpose allows you to make all measurements with one device [6]. Both in measuring the tool and inequality of the obtained surface, the focus variation technology is used, which allows detailed imaging of the complex geometry of rotary tools. In the studies described in this publication, an InfiniteFocus G5 microscope was used at the headquarters of ITA. It enables the detection of rounded edges of several micrometers and the measurement of strongly inclined surfaces. The resolution of this device allows for reliable measurements of surface irregularities in almost the entire range of quantities obtained in machining [5].

\section{Focus Variation}

Focus variation microscopy is a surface measurement technology based on finding the best focus position of the

\footnotetext{
* Mgr inż. Michał Mendak (michal.a.mendak@doctorate.put. poznan.pl), prof. dr hab. inż. Michał Wieczorowski (michal.wie czorowski@put.poznan.pl), mgr inż. Karol Grochalski (karol.grochalski@put.poznan.pl), dr inż. Bartosz Gapiński (bartosz.gapinski@put.poznan.pl) - Zakład Metrologii i Systemów Pomiarowych, Instytut Technologii Mechanicznej Politechniki Poznańskiej
}

optical system relative to the measured sample. The measurement is carried out by scanning in the $Z$ axis and continuously monitoring the change in contrast (sharpness) between neighboring pixels (fig. 1), while at the same time for the write of the focus coordinates for each pixel. By repeating the vertical scans, keeping the gaps, a point cloud reflects the measured surface.

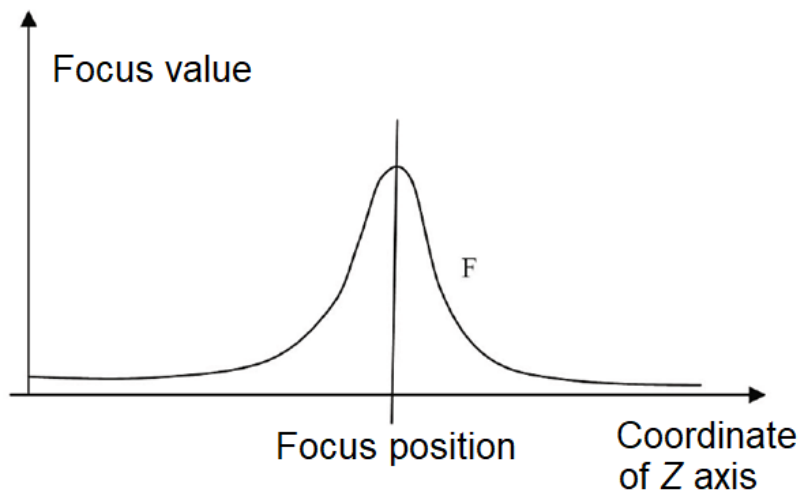

Fig. 1. Course of change of point focus value during scanning in the $Z$ axis

The position of the point is calculated from the maximum value of the fitted focus curve [6].

\section{Course of research}

The subject of the research were two spherical, fourspherical cutters, intended for roughing and semi-finishing, and an object with test geometry, engaging both the central (tip) part of the cutter and the remaining spherical part of the tool.

One side of the test part consisted of a cross-shaped slot with spherical geometry at its center. On the other hand, there was a test geometry, consisting of the geometries often encountered in machining: rounding, chamfering, $45^{\circ}$ chamfer. 


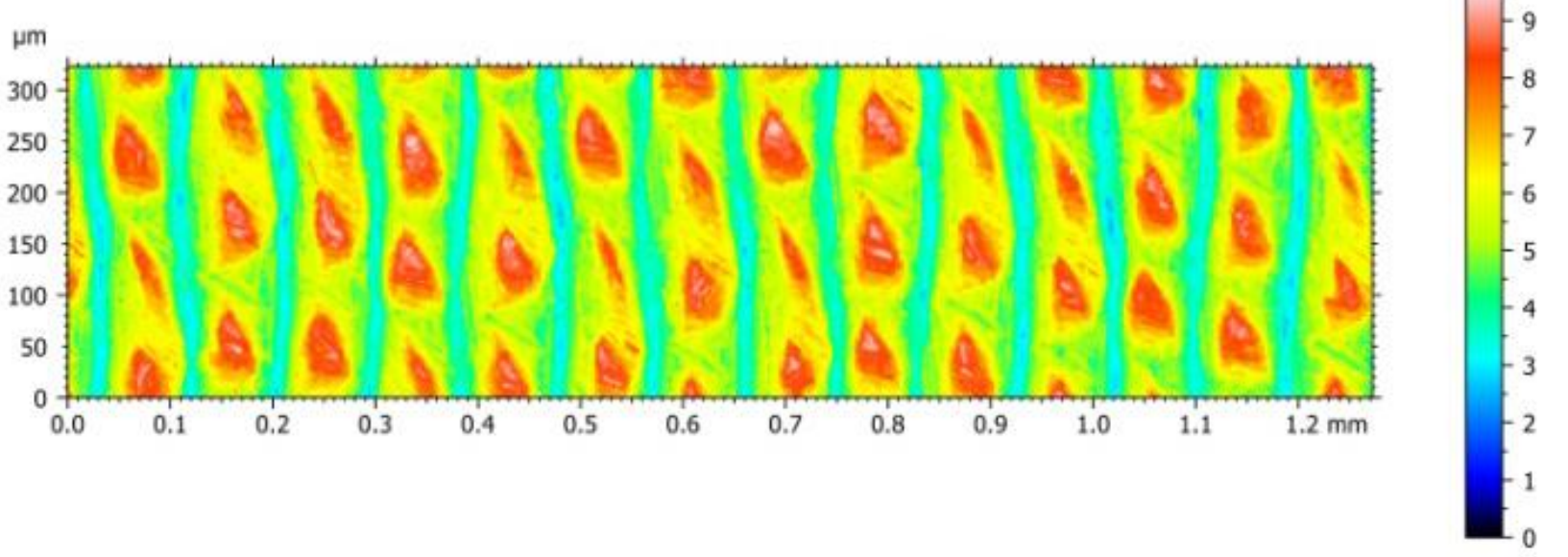

Fig. 2. Image of the surface after machining with tool 1

The slots on the first side were made with the same parameters, and the purpose of this treatment was to reach initial wear of the cutting edge. A second test geometry was made with three different cutting parameters. In each case, a three-axis machining was performed, with the spindle axis coinciding with the $Z$ axis of the workpiece.

Both before and after the machining, tool geometry measurements were performed by performing highresolution scans for each blade. Individual scans of the apical parts of both tools were also made.

\section{Analysis of results}

The use of the focus variation microscope allowed the measurement of the surface to be tested and the extraction of up to several thousand profiles much faster than would be the case with the contact profilometer measurement. In addition, the impact of the randomness of the profile distribution was offset.

Fig. 2 and the results of the roughness measurement in the form of the arithmetic mean value for 300 profiles distributed evenly over the entire measurement surface. The parameters of each profile were determined with the same filtration parameters, based on the ISO 4288 standard.

a)

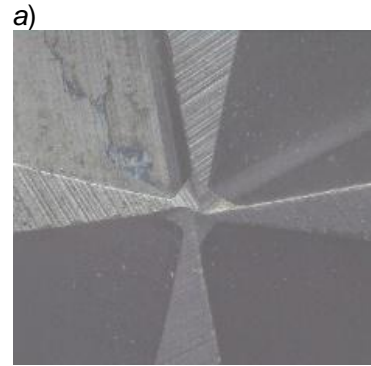

Fig. 3. Tool geometry: a) tool $1, b$ ) tool 2

Spatial parameters were also examined: $S a, S q$ and $S z$, corresponding to parameters of the roughness profile [7]. Fig. 4 shows a clear downward trend for each parameter. Note the significantly lower values of the corresponding parameters for tool 2, which results from a different geometry of its apex (fig. 3 ).

The central part of the tool 2 has been ground off, eliminating the zero point of the cutter. Thanks to such a treatment, the work characteristics of the tool is similar to a toroidal milling tool, and at the same time allows you to shape a slanted tool.
The results in the form of a point cloud were converted into 3D models, which were then superimposed on each other and deviation maps were obtained in this way.

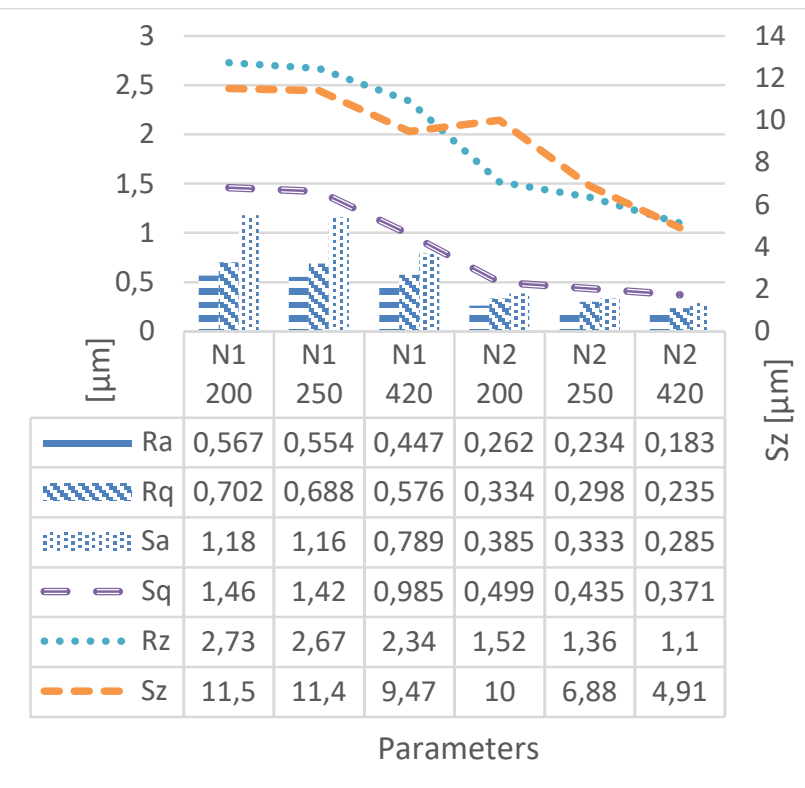

Fig. 4. Values and course of changes in roughness parameters and surface topography parameters. N1, N2 - tool markings; 200, 250, 420 - cutting speed $v_{\mathrm{c}}$ in $\mathrm{m} / \mathrm{min}$. Feed per tooth $0.11 \mathrm{~mm}$, for $v_{\mathrm{c}}=$ $420 \mathrm{~m} / \mathrm{min}$ feed per tooth $0.06 \mathrm{~mm}$

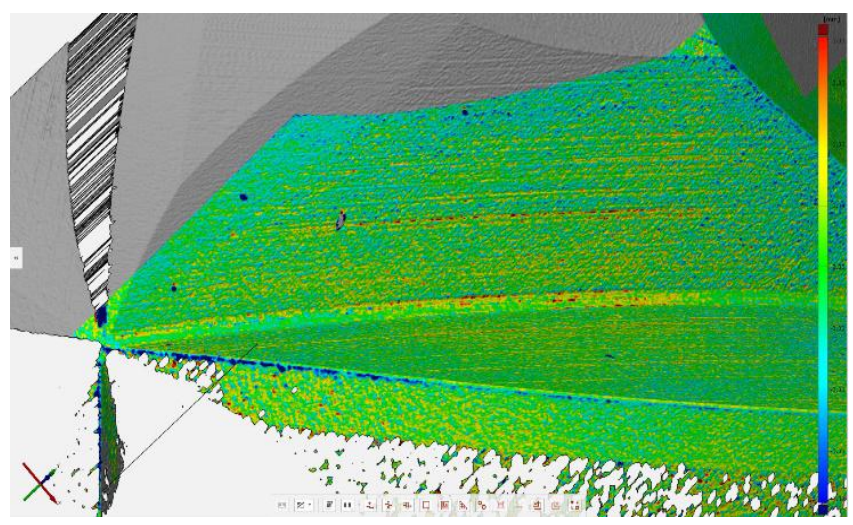

Fig. 5. Map of geometrical deviations; tool 1 
Fig. 5 and 6 show the effect of superimposing the models obtained before and after machining. On the cutting edge, in the area of the longest-loaded work in the material, losses are visible. There is a concentration of these defects on the flank. The deviation values are within $\pm 3 \mu \mathrm{m}$.

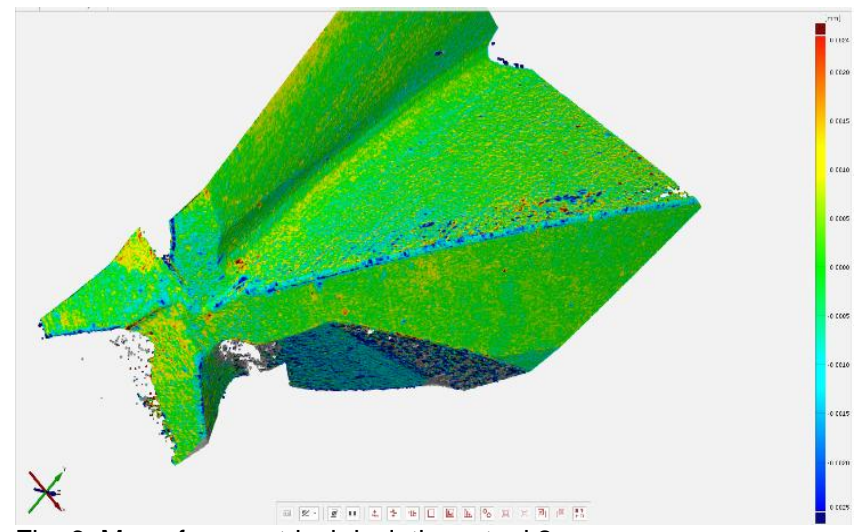

Fig. 6. Map of geometrical deviations; tool 2

\section{Reliability of measurement}

The focus variation microscope, like any optical device, is susceptible to light effects, including reflections, local x-rays, surface lensing, etc. [6, 8]. All these aspects had to be taken into account when preparing the measurement. A number of test measurements were made, including measurements of the entire geometry in the five-axis mode.

As far as criteria for the reliability of the measurement are concerned, there were no visible artifacts on the surface and stitching errors, as well as no areas with a reduced resolution of the surface.

Measurement of tool 2, having a matt coating, did not generate any artifacts, indicating increased measurement uncertainty. Only slight modifications to the direction of light from external illumination were necessary to avoid sporadic reflections. Both three- and five-axis measurements showed exceptional purity, i.e. lack of artefacts

Measurement of the tool 1, with a glossy coating, with partially exposed native material on the cutting edge, was burdened with a significant number of artifacts, and in the fiveaxis measurement there were errors in the stitching, especially on the cutting edge (fig. 7). There were also visible local changes in surface resolution, resulting in its smoothing.

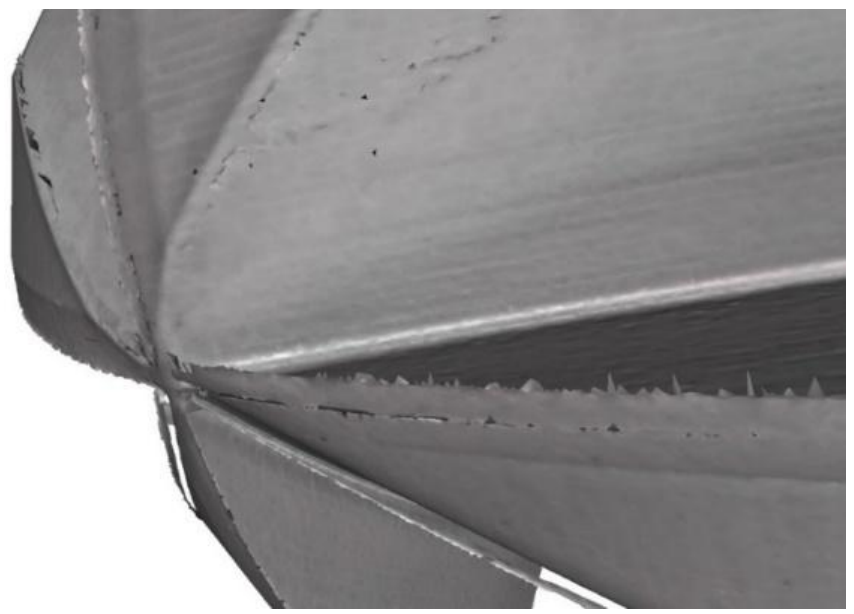

Fig. 7. Rejected measurement of tool 1 - visible artifacts and stitching errors

With this tool, only three-dimensional measurements of individual blades showed sufficient repeatability to qualify for further testing (fig. 8). It was possible only with the polarizer and after adjusting the parameters of the incident light (time of exposure, contrast, direction of lighting). The experience and skills of the person who sets up the measurement are also decisive.

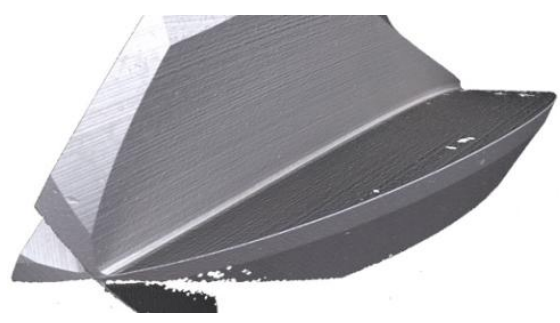

Fig. 8. Correct measurement of tool 1

\section{Conclusions}

The focus variation microscope is a versatile device that can be used to completely evaluate the effects of manufacturing processes. A multitude of lighting settings and measurement parameters allows to reduce the impact of artifacts and optical effects on the reliability of the measurement.

The 3D models of the machined surfaces showed diametrical differences in the unevenness obtained during machining with tools of different geometry. Both 3D models and the obtained inequality parameters indicate the benefits obtained from removing the zero point of the ball mill. Such a procedure caused a decrease of $R a$ and $R q$ by about $50 \%$.

Measurement of the tool before and after machining made it possible to visualize the material losses created on the tool. Available high-resolution measurements allow detection of losses below $1 \mu \mathrm{m}$.

Presented results of research carried out in the scope of research task no. 02/22/DSPB/1432 were financed from subsidies for science awarded by the Ministry of Science and Higher Education.

The microscopes of focal differentiation used for the needs of the conducted research were provided by the ITA company from Skórzewo near Poznań.

\section{REFERENCES}

1. Brzozowski D., Wieczorowski M., Gapiński B. „Pomiar geometrii i ocena powierzchni narzędzi za pomocą mikroskopu różnicowania ogniskowego". Mechanik. 11 (2017): pp. 1020-1022.

2. Chwalczuk T., Rybicki M., Korzeniewski D., Przestacki D. "Surface roughness after turning of aircraft materials". Mechanik. 10 (2016): pp. 1312 1313 .

3. Danzl R., Helmli F. "Geometry and wear measurement of cutting tools". Int. Conf. on High Performance Cutting. Dublin, 2008.

4. Segebade E., Zanger F., Schulze V. "Influence of different asymmetrical cutting edge microgeometries on surface integrity". $3^{\text {rd }}$ CIRP Conference on Surface Integrity. Procedia CIRP. 45 (2016): pp. 11-14.

5. Danzl R., Helmli F., Scherer S. "Focus Variation - a robust technology for high resolution optical 3D surface metrology". Journal of Mechanical Engineering. 57, 3 (2011): pp. 245-256.

6. Leach R.K. "Optical Measurement of Surface Topography". Berlin: Springer-Verlag, 2011, ISBN 978-3-642-12012-1.

7. Wieczorowski M. „Teoretyczne podstawy przestrzennej analizy nierówności powierzchni”. Inżynieria Maszyn. 18, 3 (2013).

8. Hiersemenzel F., Petzing J.N., Leach R.K., Helmli F. "Areal texture and angle measurements of tilted surfaces using focus variation methods". Universite de Savoie. Loughborough's Institutional Repository, 2012.

Translation of scientific articles, their computer composition and publishing them on the website www.mechanik.media.pl by original articles in Polish is a task financed from the funds of the Ministry of Science and Higher Education designated for dissemination of science. 